Article

\title{
Whose Health in Whose City? A Systems Thinking Approach to Support and Evaluate Plans, Policies, and Strategies for Lasting Urban Health
}

\author{
Silvio Cristiano ${ }^{1,2,3,4,5 *(D)}$ and Samuele Zilio ${ }^{6}$ (D) \\ 1 Department of Environmental Sciences, Informatics and Statistics, Università Ca' Foscari Venezia, \\ 30172 Venice, Italy \\ 2 Department of Molecular Sciences and Nanosystems, Università Ca' Foscari Venezia, 30172 Venice, Italy \\ 3 Institute for Global Challenges, Università Ca' Foscari Venezia, 30123 Venice, Italy \\ 4 Department of Civil, Environmental and Architectural Engineering, Università degli Studi di Padova, \\ 35131 Padua, Italy \\ 5 Interuniversity Department of Regional and Urban Studies and Planning, Politecnico di Torino, \\ 10125 Turin, Italy \\ 6 Institute for Renewable Energy, EURAC Research, 39100 Bolzano, Italy; samuele.zilio@eurac.edu \\ * Correspondence: silvio.cristiano@unive.it or silvio.cristiano@unipd.it or silvio.cristiano@polito.it
}

check for updates

Citation: Cristiano, S.; Zilio, S. Whose Health in Whose City? A Systems Thinking Approach to Support and Evaluate Plans,

Policies, and Strategies for Lasting Urban Health. Sustainability 2021, 13, 12225. https://doi.org/10.3390/ su132112225

Academic Editors: Andrea Rebecchi and Marija Jevtic

Received: 20 September 2021

Accepted: 2 November 2021

Published: 5 November 2021

Publisher's Note: MDPI stays neutral with regard to jurisdictional claims in published maps and institutional affiliations.

Copyright: (c) 2021 by the authors. Licensee MDPI, Basel, Switzerland. This article is an open access article distributed under the terms and conditions of the Creative Commons Attribution (CC BY) license (https:/ / creativecommons.org/licenses/by/ $4.0 /)$.

\begin{abstract}
An increasing interest has been present in scientific literature and policy making for the links between urban environments and health, as also learnt from the COVID-19 pandemic. Collaboration between urban planning and public health is therefore critical for enhancing the capabilities of a city to promote the well-being of its people. However, what leverage potential for urban health can be found in existing plans, policies, and strategies that address urban health? Starting from the relationship between urban systems and health issues, the purpose of this contribution is to broaden the systemic knowledge of urban systems and health so as to try to figure out the impact potential of local urban governance on public health. Considering the systemic nature of health issues, as defined by the World Health Organisation, this is done through a systems thinking epistemological approach. Urban health proposals are studied and assessed in four European cities (Copenhagen, London, Berlin, and Vienna). Current criticalities are found, starting from the guiding goal of such proposals, yet a systemic approach is suggested aimed at supporting and evaluating lasting and healthy urban planning and management strategies.
\end{abstract}

Keywords: urban health; healthy cities; systems thinking; urban governance; public health

\section{Introduction}

Public health has had a crucial role in the development of modern and contemporary urban planning. In the first industrial cities, sanitation improvement was the most urgent demand of several strata of society for the betterment of their poor living conditions [1] The necessity of addressing this issue pushed local administrations to adopt new and innovative plans and policies that radically changed the built environment (see Haussmann's renowned renovation of Paris). However, during the last fifty years, urban planning has drifted away from its roots [2]. The dynamics of globalisation have affected the way cities are planned: from a health-driven perspective to a profit-driven perspective [3]. Today, we are witnessing a renewed interest in urban planning as an enabler of public health [4], which was definitely magnified by the COVID-19 pandemic.

Cities face numerous health challenges now and into the future [5]. According to the World Bank [6], 4 billion people live in urban areas (hence the relevance of "urban health"). Projections show that urbanisation combined with the overall growth of the world's population could add 2.5 billion people more to urban areas by 2050 [7], possibly the biggest migration in human history. How to adequately manage this phenomenon is 
at the core of the New Urban Agenda (NUA) [8], an overarching document for achieving the urban dimension of the 17 Sustainable Development Goals (SDGs) [9] based on the assertion that "the good health of all its citizens is one of the most effective markers of any city's sustainable development" [10]. Besides SDG \#3 (good health and well-being), also \#6 (clean water and sanitation), \#7 (affordable and clean energy), \#11 (sustainable cities and communities), \#13 (climate action), and \#15 (life on land) are supposedly aimed at helping to improve quality of life in cities. The important connection between urban planning and public health is also strengthened by the long-established project of the World Health Organisation (WHO) on Healthy Cities [11]. According to the WHO, a healthy city is "one that is continually creating and improving those physical and social environments and expanding those community resources which enable people to mutually support each other in performing all the functions of life and in developing to their maximum potential" [11]. Actually, "Health for All" is the "historical" goal set by the WHO with the Declaration of Alma Ata to affirm that health is a fundamental human right [12]. Nevertheless, accessibility to primary health care is strongly related to socioeconomic inequities [13]. As pointed out by Vlahov et al. [14], "central to understanding and acting on urban health problems is appreciating the health realities of different communities and populations within cities". Researchers have shown that living in deprived neighbourhoods may have negative effects on the physical, mental, and social well-being [15].

Adequate urban planning can be a key factor for better overall health [16]. However, this challenge requires an approach that recognises cities as complex systems and engages with all the different dynamics that take place within them [16]. Urban policies affect the air we breathe, the quality of the spaces in which we move, the water we drink, and our access to food [17]. Well-planned cities can offer unique opportunities to minimise health risks linked to urban lifestyle (e.g., pollution, sedentariness, and stress) and the spreading of Non-Communicable Diseases (NCDs) — cardiovascular diseases, cancer, diabetes, and chronic respiratory diseases, representing the leading cause of death worldwide (70\% globally) [18]. As stated by the WHO [19], "the context of people's lives determines their health". Worldwide, the potential positive impact of urban design interventions in quality of life is widely recognised. Over the past 10 years, there has been growing interest in the potential of Nature-based Solutions (NbS) to mitigate climate change [20], enhance biodiversity [21], and also improve urban health [22].

The COVID-19 crisis has shown that many topics are interlinked and that new thinking comes from breaking silos. In addition, the European Union (EU), widely considered as a global leader in innovation, is recognising the need for some change. The European Commission has stated its willingness to step up urban governance programmes to ensure that the way citizens produce, consume, commute, and interact within cities has a positive impact on their physical, mental, and social well-being [5]. As evidenced by the pool of pioneering local solutions dealing with the implications of health issues-e.g., see EUfunded project: VARCITIES (Project title: Visionary Nature-based Actions for Health, Well-being and Resilience in Cities, Duration: September 2020-February 2025, Funded under: H2020-EU.3.5.2., Grant agreement ID: 869505, website: https:/ /www.varcities.eu/, accessed on 25 July 2021), IN-HABIT (Project title: INclusive Health And wellBeing In small and medium size ciTies, Duration: September 2020-August 2025, Funded under: H2020-EU.3.5.2., Grant agreement ID: 869227, website: https:/ / www.inhabit-h2020.eu/, accessed on 25 July 2021), GoGreenRoutes (Project title: GO GREEN Resilient Optimal Urban natural, Technological and Environmental Solutions, Duration: September 2020August 2024, Funded under: H2020-EU.3.5.2., Grant agreement ID: 869764, website: https: / / gogreenroutes.eu/, accessed on 25 July 2021), and euPOLIS (Project title: Integrated NBSbased Urban Planning Methodology for Enhancing the Health and Well-being of Citizens: the euPOLIS Approach, Duration: September 2020-August 2024, Funded under: H2020EU.3.5.2., Grant agreement ID: 869448, website: https:/ / eupolis-project.eu/, accessed on 25 July 2021)—European cities are trying to lead the way towards a more sustainable future. Between 2014 and 2020, more than 680 cities implemented sustainable development 
strategies, and the ambitious agenda of the European Green Deal (EGD) [23] promises to boost this transition (interestingly, all of the policy areas of the EGD are implemented in cities) [24]. Warnings exist about possible structural issues hiding behind the EGD's narrative [25] - "simultaneously a source of hope because of its generative potential in providing a new example of an ambitious green policy and a slap in the face as it renews the European commitment to a growth paradigm" [26] - and allegedly sustainable approaches in European cities [27]. This can be seen as an additional reason for further exploring such themes.

Health is largely determined by policies outside the health sector [28]. One of the earliest lessons learnt from the COVID-19 pandemic was the acknowledgement of the need for changes in how built environments are designed [29]. As we said before, urban areas have an important role to play in supporting public health measures and reducing the risk of infections. They are, themselves, determinants of health [30]. In a recent work, Martínez and Short [31] highlight urban issues related to the health crisis and suggest considering them as an opportunity to rethink cities. Proponents of the 15-min city (FMC) concept, a neighborhood-centered approach to urban planning which gained popularity due to the COVID-19 pandemic [32], are already promoting a reorganisation of the city [33]. Far from being a "brand-new" strategy, this model "uses long-established urban planning principles to achieve a bottom-up promotion of well-being" [34]. The newly released Mayors' Agenda for a Green and Just Recovery specifically mentions the idea of FMC as a framework of reaffirming the commitment of cities to improving our health [35]. Whether with the FMC or another urban planning model, policy makers should systematically take into account the health implications of their decisions [36].

Ultimately, collaboration between urban planning and public health is critical for enhancing the capabilities of the built environment to promote well-being and to develop policies aimed at transforming our cities into sustainable, therefore healthier, places [37]. Although, the overall sustainability of a city requires a holistic-systemic perspective that is frequently still lacking when addressing urban policy-making procedures [38]. Based on such preliminary remarks, the purpose of this contribution is to broaden the systemic knowledge of urban systems and health so as to suggest a comprehensive approach rooted in systems thinking to lasting healthy urban planning and urban governance strategies.

General research question: how do selected urban health policy proposals relate to health, as defined by the World Health Organisation?

Specific research questions: from a systemic perspective, what leverage potential for urban health can be found in existing plans, policies, and strategies that address urban health? Is there any under- or overrated approach? Is there any neglected action promising some higher leverage potential for lasting urban health?

\section{Method and Materials}

\subsection{An Epistemological Tool Rooted in Systems Thinking}

Urban health and healthy city policies are here studied in present and prospective regular conditions. This is done through a systems thinking (ST) epistemological approach. A descriptive framework of the health dimensions of a city is developed by means of the energy systems language [39], adopting stock-and-flow symbols (see also [40]). ST has its roots in the pioneering oeuvres by von Bertalanffy [41] and Forrester [42], yet different approaches have been developed and refined over time to meet different scopes. Among them, approaches such as System Network Analysis, Causal Loop Diagrams, System Dynamics, and Agent-based Modelling are usually listed (and usually require computer simulation, [43]) but are not at the core of the present study. As a matter of fact, here we refer to the work by ecologist and systems scientist Howard T. Odum [44,45] and specifically to its sophisticated method to describe and-if need be-quantify the operation of complex systems. This can be made by drawing a research tool based upon a comprehensive stock-flow diagram that encompasses all of the resource flows that participate in the dynamics of the studies system: matter, energy, information, labour, and monetary flows. 
ST has been applied to manifold fields, from environmental studies to social sciences and management (see e.g., [46-48]). ST goes past linearly describing the facts and local cause-effect links of a system and rather addresses the structure of pattern configurations, emerging from the self-organised connections and feedback processes that are crucial in the stability and resilience of such a system [40-49]. The comprehension of a system's pattern configuration does not necessarily demand quantitative analyses [50]. One of the main features of a ST-based study is the systemic diagram, including processes, stocks, and flows able to describe the operation of a system at a certain level of detail [51,52]; indeed, details exceeding the level of interest can allow for components to be grouped together according to the ST technique of the macroscope [45], thus highlighting their main influences [53]. A system is assigned a boundary, whose meaning is not only physical but also tells external drivers from internal operations-a choice ultimately related to the goal of the study - thus allowing one to define inflows and outflows [38]. Stocks represent the main assets and resources contributing to the operations of a system (here, a city); like flows, they may be expressed-when needed-by extensive variables, and can be either material or immaterial [50]. Processes can change a flow, as a result of the interaction of different types of flow producing at least an outflow; processes can also determine or be influenced by some feedback flows with control functions, exerted by some stocks in the system [50]. Feedbacks, organised in hierarchical structures, are a key aspect of systems diagramming [54]. One of the main scopes of an ST-based study is to identify the material or immaterial sub-structures upon which a given system depends [38], where an even tiny change may affect the entire system, i.e., leverage points: crucial places in which to intervene in a system [55].

\subsection{Systems Thinking, Cities, and Health}

Various types of systems-based approaches have been applied to cities and/or health, sometimes exhibiting different theoretical bases and different research goals.

\subsubsection{Systems Thinking and Cities}

Some pioneering works were already associating cities with the potential of systems thinking while this concept was first being developed [56] and refined [57]. Yet today a systemic approach seems still far from being operationally conceptualised-and least of all adopted-in general urban planning and governance. Decades after Odum, Peterson, and Mandelbaum, it was apparently still possible to deal with systems thinking as a frontier approach to forward-looking urbanism: "Cities are unique complex adaptive systems. New Urbanists need to know as much as possible about complex adaptive systems theory and research, and look for ways to apply the insights and thinking to their everyday work-our future depends on it." [58]. Since then, systems thinking has been relaunched in urban studies as a tool to pursue sustainable decision-making [59] and "to clarify the consequences of our actions, identify our options, and extend our foresight a bit" [60]. More recently, Bedinger et al. [61] state and motivate some "need for a pluralistic framework for urban systems", while Scrieciu et al. [62] suggest undertaking a common effort by systems thinking and complexity economics to address urban sustainability while not venturing into a proper evaluation and instead acknowledging that both approaches elude a commonly shared definition. This can be seen as generally applying to many publications about systems thinking and cities. As to the poor translation of theory into practice, exceptions mostly regard systems thinking applications to smart cities [63], frequently limited to conference proceedings $[64,65]$ and focused on information technology and big data [66,67]. As a matter of fact, systems thinking is often associated with computer science [43], and this can be framed within the elusive definition of the systemic approach. However, in the present paper a preference is expressed for systems diagramming through energy systems language-as shown above-and for its connected "two-fold epistemological valence" [50], allowing one to understand how the configuration of the resource flows network in an urban system adapts to the socioeconomic choices in that city, while also 
(but not only) allowing for the computer-aided quantification of its urban metabolism [50], as respectively theorised and performed in Xue et al. [68] and Xue et al. [69]. Such an approach learns from physics—as encouraged by Pollock [70] for fruitful applications of systems thinking to cities-but opens up to humanities and social sciences, including urban planning and governance. Apart from the founding theory by Odum, this work is inspired on its conceptualisations and applications to urban and regional studies by Cristiano and Gonella [50], focusing on regional planning and, more specifically, on transport infrastructures; Cristiano et al. [71], modelling a general city while considering both its energy and material flows and its cultural dimensions; and Cristiano and Gonella [38], addressing the complex case of urban touristification, focusing on (but not limiting to) the iconic city of Venice, Italy.

\subsubsection{Systems Thinking and Health}

A separate discourse can be dedicated to systems thinking and health. One of the first traces of systems thinking being brought into the debates on public health management can be found in Lammers and Pandita [72], with McLeroy [73] later praising ST's potential "to provide new and critical ways of framing public health and public health concerns, with particular emphasis on the social and behavioral sciences". However, Chugtai and Blanchet [74] observe how ST is an increasingly popular topic in public health, although its understanding and approaches are sometimes unclear; specifically, their literature review records a growth of publications about ST and health in the 2010s, with 2014 as the most prolific year up to then. In that year, Peters [75] explores the added value of applying some systems thinking approaches to public health research; among its findings, ST "provides new opportunities to understand and continuously test and revise our understanding of the nature of things, including how to intervene to improve people's health". Adam [76] stresses how applying systems thinking to design and evaluating health programmes would be particularly beneficial for low- and middle-income countries. Sarriot et al. [77] use a participatory method to stimulate creative thinking from stakeholders for the improvement of a health system in Northern Bangladesh. Rwashana et al. [78] use causal loop diagrams to understand neonatal mortality in Uganda; the same approach is applied by Agyepong et al. [79] to assess some aspects of Ghana's national health insurance scheme and by Varghese et al. [80] to understand the immunisation services in Kerala, India; prior to this, Proust et al. [81] had used it to start to find the leverage points for human health adaptation to climate change in urban environments. Battle-Fisher [82] uses system dynamics to model health policies in some selected case studies in the USA; Bishai et al. [83] employ the same simulation tool to understand why cure crowds out prevention in a society. Williams [84] uses input, output, feedback, and throughput variables to understand and build a conceptual model of healthcare reform proposal in the United States of America. Carey et al. [85] conducted a systematic review on the application of systems science to public health, identifying four research categories, "ranging from editorial and commentary pieces to complex system dynamic modelling". Causal loop diagrams are used again by Berry et al. [86] to study the relationship between climate change and mental health; by Knai et al. [87] to analyse the commercial determinants of non-communicable diseases and, in particular, the influence of unhealthy commodity industry onto public health policies; and Clarke et al. [88] to understand obesity prevention policy processes. Li et al. [89] proposed a socioecological systems approach as a conceptual tool to study climate change impacts on urban health. In recent years, new praises to systems thinking are made to address planetary health [90] and, specifically, the health- and well-being-related Sustainable Development Goals [91]. Even more recently, Haley et al. [92] offered a critical inquiry into the value of using systems thinking to analyse COVID-19 crisis, including both effectiveness in healthcare and health prevention and implied societal inequalities. Recent systems thinking works dealing with health and falling within our same approachas defined above - are authored by Cristiano et al. [93], performing a quali-quantitative systems thinking evaluation to understand the sustainability and resilience of health sys- 
tems, with a focus on a Sub-Saharan African cardiac surgical healthcare network based in Khartoum, Sudan; by Romano et al. [94], to study the interaction of RNA virus-host interaction; and by Cazzagon et al. [95], to visualise theranostic approaches to solid tumours in personalised nanomedicine.

\subsubsection{Systems Thinking, Urban Health, and Healthy Cities}

If a general conceptualisation of cities through systems thinking is still quite a novelty, as outlined above, sectorial applications can be found, and those concerning urban health are no exception. Tozan and Ompad [96] propose a conceptual essay, reviewing the usefulness of applying system dynamics' concepts, principles, and methods to investigate urban health issues: "System dynamics models can be used for testing the viability of policies in an inexpensive way (i.e., often with existing quantitative and qualitative data) and can illustrate the tradeoffs and unintended consequences of policy choices related to the allocation of public health resources, particularly in resource-constrained settings". A review on the potential utility of applying systems approaches "to understand and act on health in cities" is also offered in Roux [97], with Newel and Siri [98] specifically focusing on the potential of causal-loop-based low-order system dynamics in urban health policy making. Auchincloss et al. [99] briefly propose an introduction to agent-based modelling to approach urban health. Lawrence et al. [100] called for some sort of collaborative systems thinking to address contemporary urban health challenges across conventional disciplines, including human ecology. Kim et al. [101] use causal loops to explore urban walking and health promotion in Seoul, South Korea; the same approach is used by Tan et al. [102] to evaluate urban health policy proposals in Kuala Lumpur, Malaysia; by Siri and Tan [103] for a macroscopic approach to urban health and well-being in the Asia-Pacific region; and by Pineo et al. [104], who developed loop diagrams from semistructured interviews with urban health indicator producers and users in San Francisco, California and Melbourne and Sydney, Australia, for the improvement of local urban planning policies. Thinking in terms of ecological systems is at the basis of a new proposal for moving towards a multispecies sustainability as a key driver to imagine and plan healthy cities [105]. Instead, community-based system dynamics are used by de Oliveira Morais et al. [106], matched with participatory processes, to inform urban health policies in São Paulo, Brazil, with a focus on food and transportation; and by Browne et al. [107] to approach Aboriginal health on the lands of the Wurundjeri, Wathaurong, Gunditjmara, Taungurung, Yorta Yorta, Wiradjuri, and Eora peoples. After presenting an experiment for health improvement in Beirut, Lebanon [108], focusing on public transport, green spaces, and walkability planning strategies, Liu et al. [109] offered an evolutionary complex systems perspective on urban health, highlighting the mismatch between the invasive and exploitative growth of urban economies on the side, and the reduced resilience of humans as biological organisms. The need for systems thinking (and more generally transdisciplinary approaches) is reasserted in a paper reporting the outcomes of a global workshop on urban planetary health research [110]. Systems thinking is often matched with computer aid and artificial intelligence, as remarked by the National Academy of Sciences et al. [111] within the "smart city" discourse. To the best of the authors' knowledge, a general systems thinking conceptualisation of the health dimensions in cities is still lacking; the present paper is framed within the context of this absence.

\subsection{Defining Health}

According to the constitution of the World Health Organisation, in force since 1948, health is defined as "a state of complete physical, mental and social well-being and not merely the absence of disease or infirmity" [112]. "The enjoyment of the highest attainable standard of health is" recognised as "one of the fundamental rights of every human being without distinction of race, religion, political belief, economic, or social condition [112]. The health of all peoples is linked to peace and security and the promotion and protection of health is assumed as a value to all, while the unequal development of such actions in 
different countries is seen as a global danger [112]. To achieve all of this, governments are bound to "the provision of adequate health and social measures." The systemic nature of health issues can be implicitly found in such a constitution, and some explicit exploration is offered in the rest of the present paper.

\subsection{Selected Case Studies on Health and the City}

The health dimension in cities is explicitly treated in some advanced local plans. In the light of the role of Europe in the matters at hand, as illustrated in our introduction, a focus is here dedicated to European capitals and largest cities. Given the first 25 cities in Europe by population, we have filtered them by population [113] and quality of life (in this case, considering the first available ranking before the pandemic — status quo) [114] to select the first 2 cities respectively. Such a selection has resulted in the choice of four case studies, namely from London [115], Copenhagen [116], Berlin [117], and Vienna (Wien) [118] (each of these four references also refer, respectively, to the citations in Section 2.4.1, Section 2.4.2, Section 2.4.3, and Section 2.4.4). In the former pair, policy tools are explicitly dedicated to urban health issues, including health promotion and inequality in health access. In the latter pair, such issues are at least mentioned in local plans, where health promotion is considered as a co-benefit from their implementation. Some highlights of the selected policy tools are offered in Table 1. Besides the interest in analysing the way the largest and liveable cities address health in their local urban policies, the bridge that led us to the selection of our case studies is built on the three key concepts of validity, reliability, and generalisability, that are commonly used to assess the value of quantitative and qualitative research [119]. The chosen policy tools are: (1) valid, because they provide a certain level of data/information availability that is strongly needed to evaluate their contribution to health and well-being; (2) reliable, because they are relevant in today's date within the European urban planning context. Poulis et al. [120] highlight the role that context plays in the case selection process and the importance of contextualised sampling processes for case study research; (3) generalisable, because there is homogeneity among them (here, a fair level of generalisability is of course possible among Global Northern cities, and particularly in European ones). According to Patton [121], if variation among cases is minimised then the analysis is simplified and the study is typical-case focused.

Table 1. Highlights of the selected case studies on health and the city.

\begin{tabular}{|c|c|c|}
\hline Policy Tool & Vision or Narrative & Declared Approach \\
\hline $\begin{array}{l}\text { City of Copenhagen Health } \\
\text { Policy 2015-2025 }\end{array}$ & $\begin{array}{l}\text { a common framework } \\
\text { to eliminate social inequality } \\
\text { in health }\end{array}$ & $\begin{array}{l}\text { direct impact on health by launching action } \\
\text { plans across all sectors }\end{array}$ \\
\hline $\begin{array}{l}\text { London Health } \\
\text { Inequalities Strategy }\end{array}$ & five key aims to tackle health inequalities & $\begin{array}{l}\text { direct impact on health by addressing the wider } \\
\text { determinants of health }\end{array}$ \\
\hline Berlin 2030 Urban & economic strength, quality of life, & indirect impact on health by pursuing strategies \\
\hline Development Concept & and social conscience & to face sustainable development challenges \\
\hline $\begin{array}{l}\text { Smart City Wien Framework } \\
\text { Strategy 2019-2050 }\end{array}$ & $\begin{array}{l}\text { high quality of life for everyone through } \\
\text { social and technical innovation in all areas, } \\
\text { while maximising conservation of resources }\end{array}$ & $\begin{array}{l}\text { indirect impact on health by implementing } \\
\text { projects on different thematic fields }\end{array}$ \\
\hline
\end{tabular}

\subsubsection{Copenhagen}

The City of Copenhagen [116] defines health as "a long and enriching life", with physical and mental well-being. Yet some "unacceptable health inequality" is detected, with "socioeconomic advantages, higher education, stable labour market affiliation, and strong social relations" being linked to "markedly better health and fewer mental problems"; besides "debilitating occupational health problems or an unhealthy lifestyle", such an inequality is also associated with "conditions established early in life". Actions are proposed toward: "education and access to healthy food and exercise during school time"; "green urban spaces for people of all ages, vibrant recreational clubs and societies, healthy 
workplaces and environmental transport options, such as super bicycle paths"; the setting of "the right priorities, so help goes where it is most needed"; helping "to quit smoking, tackle stress or deal with alcohol abuse"; and addressing "physical inactivity" and "poor mental well-being". Actions for citizens with mental problems include "enabling more people to enjoy good, high-quality lives and take an active part in society". The urban environment, "with its noise and air pollution", is recognised as affecting Copenhageners' health, "while the city's physical layout and accessibility impact the way Copenhageners of all ages use the squares and parks for activities, contemplation and tranquillity"; accordingly, the plan suggests "we must all work more intently and broadly together to include prevention and early initiatives systematically in every part of life-from health care, day-care facilities, schools, youth educations, urban planning, workplaces, sheltered homes, activity centres and nursing care to rehabilitation therapy", while also focusing "on maintaining the effects we achieve". Implementation is expected to happen through "cooperation and partnership with others" i.e., "volunteers, patient and sports associations, housing organisations, workplaces, research institutions and private and socioeconomic businesses". Nevertheless, it is also recognised that the proponents" "knowledge about what is effective still falls short in some areas, especially when it comes to reducing social inequality in health"; consequently, they aim at understanding its causes, by also involving citizens, universities, and other research institutions.

\subsubsection{London}

The proposals by the Greater London Authority [115] are due to the Mayor's "statutory responsibility to produce a health inequalities strategy for London", according to which such inequalities "should be addressed to the mitigation of differences in general health determinants". Health inequalities are introduced, with "too many Londoners suffering ill health because of social and economic exclusion", matched with differences in "background, upbringing or financial circumstances". Like for Copenhagen, babies and young children are addressed, together with obesity, mental air, and toxic air, "all of which are harming our health and wellbeing". The concept to tackle all of this is "quality, universal provision of healthcare in London", while acknowledging that "health is also part of a wider picture", for which there would be need of "a fairer economy, a stronger and more integrated society and an environment that helps people stay fit and healthy". Speaking of health and economy, it may be useful to report an entire passage:

"When we fail to keep people healthy, demand for health and care services grows and the care Londoners need can become more complex and enduring. What's more, the health of Londoners underpins our economic growth and prosperity -London will never realise its full potential while so many Londoners struggle with poor health."

At a higher level, "[a]ddressing the wider determinants of health-the conditions in which people are born, grow, live, work and age-is the most important thing that can be done to improve this situation for Londoners, and to achieve long term change". Following the analyses and considerations above, five key aims are identified "to tackle inequalities and achieve the Mayor's vision in London over the next ten years": (1) "Healthy children" (support to children and families, with a focus on obesity, especially in the most deprived communities); (2) "Healthy minds" (will to have people "feel comfortable talking about their mental health", so as to end social stigma and "to reduce suicide rates"); (3) "Healthy places" ("access to green spaces", non-killing air, but rather "the best air quality of any major global city"; "access to good quality work", adequate incomes, "and a safe place to call home"); (4) "Healthy communities" (social integration, support to communities at risk of infections such as HIV and tuberculosis); (5) "Healthy living" ("minimum level of daily activity needed to maintain good health"; "access to healthy food"; decreased use of "tobacco, illicit drugs, alcohol and gambling"). Interestingly, the health inequalities - "avoidable and unfair"-are identified as "a result of systemic differences in the determinants of health and wellbeing. The factors that influence health outcomes are recalled and summarised from Delghren and Whitehead [122] and Barton and 
Grant [123], addressing the global ecosystem, climate, and biodiversity in relation to people and calling into question-among others-natural environments, built environments, health and care systems, economies, and communities.

\subsubsection{Berlin}

Berlin SDUDE [117] shows the city as "committed to a policy of complete solidarity with those suffering exclusion or poverty and provides the necessary systems of social support and health care". "The elimination of multiple sources of pollution and the development of green and other public spaces as meeting places and exercise areas is a particular focus" to pursue "[m]ore environmental justice and better health". By 2030, Berlin is expected to succeed "in safeguarding its natural resources sustainably for the long-term, with soil, air and water quality". Quantitative growth is expected to advance while supposedly preserving biodiversity, in spite of scientific warnings such as those by Parrique et al. [124] and by Liu et al. [109]. Some foci are dedicated to Berlin's tools to measure and forecast the influence of climate change and to apply findings to urban planning, also resulting in tackling "resource-saving mobility" and modal share shifting toward eco-mobility (walking, cycling, public transport) and electromobility. Concerning climate change, "protection and adaptation initiatives" are envisioned at the neighbourhood level, "to raise public awareness locally and apply climate efficiency principles at the community level".

\subsubsection{Vienna}

Health policies are here addressed as part of those "strategies and programmes aimed at ensuring a high level of resilience and thus at safeguarding the all-round quality of life enjoyed by the city's population". The 2050 vision of "Smart City Wien" [118] expects Austria's capital to be "in good health", i.e., "-not only are people living longer, but healthy life expectancy has also increased; the healthcare system focuses on staying healthy and active ageing". The underlying assumption is that "[o]bjectives and measures in different thematic fields often reinforce one another", e.g., "eco-friendly forms of transport also improve traffic safety, reduce noise pollution and promote health by encouraging physical exercise". Healthcare is seen as one of the twelve action areas, together with energy supply, buildings, mobility and transport, economy and employment, water and waste management, environment, social inclusion, education, science and research, digitalisation, and participation. The "access to public services such as good healthcare and nursing and care facilities" is considered as one of the contributing factors to the city's quality of life. Besides climate change related overheating, "the growing concentration of low-level ozone and new pathogens entering the region due to the changed climatic conditions can create an additional burden". Vienna is expected to be smart only "if it enables high quality of life, even on a lower income", with a highly developed healthcare system as well as more urban achievements. In a wider approach, walking and cycling are seen as "active mobility options that promote a healthy lifestyle". A focus is dedicated to "digital infrastructures, products and services" to be "only used if they are harmless to both the environment and public health"; however, "[p]otential health factors (e.g., exposure to radiation) are also to be taken into account when planning IT infrastructure". Among urban experiences, urban and community gardens are associated with healthy eating and waste reduction. Moreover, it is acknowledged that " $[\mathrm{m}]$ inimal environmental pollution and intact ecosystems are essential for healthy living conditions and a high quality of life in the city" and that "[p]revention and reduction of air, water and soil pollution and of heat and noise are thus central pillars of Smart City Wien, alongside the preservation and expansion of green spaces and countryside, soil functions and biodiversity and a healthy, sustainable diet and food production". In addition, additional key contributors "to the healthy living conditions in Vienna are the environmentally aware mobility habits and consumer behaviour of the Viennese people". A focus is dedicated to global warming and its impacts on "people's health and quality of life" and on the economy. Air, water, and soil pollution, noise and heat pollution, and light pollution are all addressed in one objective, wishing that they are 
"all minimised as far as possible": "[a]s an absolute minimum, pollution should be below the legal limits throughout the entire city". Healthy food is also briefly mentioned. More generally speaking, "[g]ood health is seen by many as the most important commodity, and is thus essential to individual well-being and life satisfaction". Two more objectives involving health are: (1) to have the healthy life expectancy of Viennese increased by two years (through the improvement of "healthy living, working and environmental conditions", including the provision of recreational areas, the reduction of environmental pollution down to minimum standards, intact ecosystems, and a healthy diet based on local/regional food, fair working conditions, and the promotion of physical activity and active mobility (walking, jogging, and cycling) "through appropriate design of public spaces"; (2) to promote health literacy at both the individual and the organisational levels.

\section{Results and Discussion}

A systems diagram has been expressly developed to address urban health discourses, building upon previous works by Cristiano et al. [71] and Cristiano and Gonella [38], and is here shown in Figure 1. In particular, the black and grey stocks and flows come from such previous works, while the red ones have been added in the light of the study and understanding of the definition of health by the WHO and of the selected case studies. The punctual explanation of specific feedbacks and triggers is offered in the next lines; direct reference to the case studies is also provided in the subsections specially dedicated to Copenhagen's, London's, Berlin's, and Vienna's plans and strategies; far from being a narrative summary of the policy tools at issue, those paragraphs represent the sources of the information that has been here systemically framed into wider urban systemic operations, also showing the peculiarities of the single case studies.

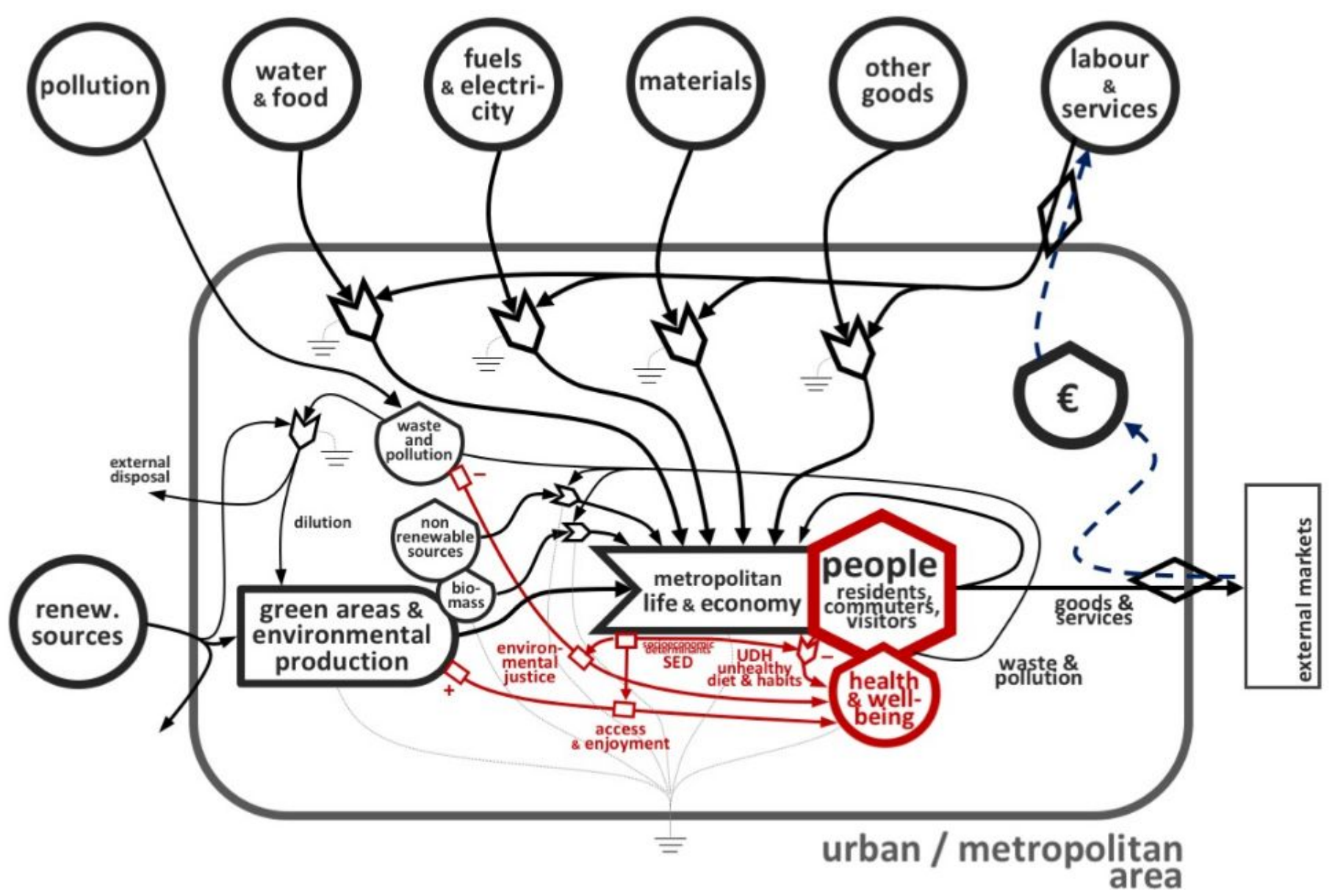

Figure 1. Systems diagram of a city in relation to its urban health (adapted and expanded from [71]; the red parts are the new contribution of this work compared to such article) (SED = socioeconomic determinants; UDH = unhealthy diet and habits). 
Similarly to a diagram for a general city, local people (residents, commuters, and visitors) are users who benefit from local (urban or metropolitan) life and economy, in turn demanding external resources to be run: water and food, energy, goods, materials, labour, and services. A peculiar stock is here highlighted, part of the wider user stock of people, i.e., their health and well-being. A city's life and economy have already direct impacts onto the health and well-being of its people-and healthcare can be meant as a part of local life and economy - yet other health determinants can be addressed separately, as also outlined in the selected case studies that are addressed in the present manuscript. There is some general agreement that socioeconomic determinants (SED in the diagram) have significant effects on health. In the studied plans and strategies, such determinants tend to be associated with unhealthy diets and unhealthy habits (UDH in the diagram). The studied plans and strategies tend to address the consequences of socioeconomic determinants, e.g., lack of physical activity, consumption of unhealthy food, obesity, or tobacco smoking. Sometimes they just wish that these issues be addressed by third parties. Even if directly and successfully addressed, though, these only represent some effects of causes that are instead left mostly unaddressed. It may be hard to find some time for physical activity after long hours of salaried work, while commuting may affect poorer citizens living in suburbs more than other citizens. Similar discourses could be made for healthy food, which can be more expensive than unhealthy options, with urban or community gardens not really likely to feed an entire city and anyway suffering from the same issues of some possible lack of such a non-universal luxury as free time, just like physical activity. Smoking may be also linked to socioeconomic factors $[125,126]$. Waste and pollution, among which climate change and urban warming may be also inserted, are addressed in all the addressed case studies. The causes for this can be found both in the local life and economy and outside the city at hand, "imported" (as pollution in the diagram). A proper strategy does not emerge in any of the studied strategies and plans and may be associated with life and economy also at higher scales. However, there is a consensus that abating waste and pollution would result in improved health and well-being. If ever achieved, some considerations may be added: as a matter of fact, it is unlikely that these be completely removed; if some waste and pollution is left, socioeconomic determinants may come again into action, with unequal distribution of waste and pollution by race and class, as outlined by the so-called environmental justice studies [127]. "Greening" the city by means of public parks and bicycle lanes is another frequent proposal to positively impact urban health. However, socioeconomic determinants may jeopardise its success, due to uneven access and enjoyment in the population, with poorer strata potentially suffering from the abovementioned lack of time and/or a longer distance to cover to reach "green" facilities that may be historically and/or structurally easy to find or to create in less densely built and populated areas of a city, which are likely to be also more valuable hence less accessible by the poor.

In addition to the general issues with urban health, as addressed above, some specific discussion can be also dedicated to the single case studies.

\subsection{Copenhagen}

Analysing the provided data in the policy for Copenhagen, it emerges that the number of years lost due to early death by traffic accidents is nearly as much as those due to alcoholism, but the latter seems bestowed with much larger importance than the former, which is not really addressed if not implicitly identifiable in a general auspice for more sustainable mobility; this is not really relevant-per se-in road safety. In the same records of morbidity and mortality, lung cancer is the highest contributor to early deaths, hence presumably the attention for discouraging smoking ("quit smoking programmes"); as outlined in the general discussion, anyway, the causes for smoking are perhaps underexplored, while they would represent leverage points with larger systemic impact on urban health Among other proposals there is some "special support to the Copenhageners in greatest need" e.g., "children growing up in families with alcohol abuse"; again, socioeconomic 
determinants may not be limited to difficult household contexts, and difficulties are likely to be symptoms of maybe less addressed socioeconomic causes (which are, to be honest, introduced and recognised as key factors in this and other documents on urban health). In Copenhagen's policy plan, an interesting motto is "an ounce of prevention is worth a pound of cure"; in practice, though, it seems more reachable to set more controllable goals such as to "ensure that the Copenhageners that need treatment receive the right help and support as early as possible". Alongside the cure-over-prevention focus, a curious aim is present "to use technology such as telehealth".

\subsection{London}

It may be interesting to note that the words "mayor" and "mayoral" appear 238 times in the 184 pages of the London Health Inequality Strategy. The fact that such a document is something mandatory for any mayor of that city, complying with a duty to reassure about the commitment of the "first citizen" seems to be emerging in the system as well as in the text. Such a strategy puts more emphasis on socioeconomic determinants than Copenhagen's policy plan. Nevertheless, no concrete action, proposal, or plan to tackle such determinants can be found; indeed, the mayor shares his suggestions for other institutions to intervene: "Because addressing health inequalities is complex, and because the Mayor does not have direct powers over many of the factors that influence health and health inequalities, the commitment, support and focus of people and organisations across London is crucial to delivering the aims of this strategy. By leading where appropriate, and encouraging others to act, the Mayor hopes to strengthen action across London to tackle health inequality now and in the future". A plan is offered for the mayor to help reduce health inequalities by "directing support from City Hall", "speaking out about health inequalities", and "ensuring all the mayor's work contributes" to planning, transport, housing, economic development, environment, culture and sport, policing, and other strategies and policies"; however, a systemic discussion of such good intentions may not be easily drawn.

\subsection{Berlin}

Based on what is illustrated in Section 2.4.3, the general comments and discussion can be considered as valid also for Berlin. However, this case study has less materials on urban health than others: as a matter of fact, in Berlin's development concept only 11 occurrences of the words "health", "healthy", or "health care" are present in 78 pages (in Copenhagen's case study, these words appear 78 times in 20 pages; in London's document, 1190 times in 184 pages.). From what is reported above about Berlin's concept, it may be important to stress a few passages. Quantitative growth is expected to advance while preserving the environment; this complies with the narrative of "green growth", implying some decoupling of the economy and its impacts, which has been anyway found as a problematic and hardly reliable claim [124]. Electric mobility is encouraging, yet this has some socioeconomic issues [128] and still implies the consumption of rare materials and - what is more - of an energy source that is even higher in the hierarchy of energy sources [129], calling into question how the available energy is obtained as well as how much of it is required upstream. Finally, climate-related concerns are addressed locally, and in the form of protection and adaptation, while we may suggest that a much larger leverage potential could be found in acting globally and on prevention, but this falls much beyond the purposes of the present paper.

\subsection{Vienna}

Stunningly, 118 occurrences of the words "health", "healthy", or "healthcare" can be found throughout 172 pages, in spite of the document not really addressing these as its main goals. However, a large part of the attention is paid to the effects of climate change that are relevant to urban health: "The growing number of very hot days is a health hazard, especially for children and elderly people" and "people in frail health". A 
focus is also dedicated to "digital infrastructures, products and services" to be "only used if they are harmless to both the environment and public health", with such reassurance deserving to be further and critically analysed. Among urban experiences, urban and community gardens are associated with healthy eating and waste reduction; as observed above, such gardens may not be sufficient to feed the whole urban population and may not be attended by anyone in light of socioeconomic issues, and — we may add — further analyses and discourses may be carried out on the healthiness of food grown in (polluted) urban areas. Back to climate change and urban warming, and conversely to the previous case study, far-sighted planning, timely prevention, and protective measures are here seen as requirements to minimise the impact, "which in turn calls for close collaboration, especially with the federal government and the EU".

\subsection{Possible Leverage Points}

In the Viennese case study, "good health" is described as "seen by many as the most important commodity" [118], and—be it a slip or something intentional—this may be considered as a first crucial step we would like to stress: health and well-being are commodified. No sign has been found of them described as part of an individual's economic, social, and cultural rights [130,131], as societal priorities, or as guiding goals of human actions. When passing from the analysis of the health inequality issues to the actual proposals that are reported in the selected case studies, it is hard to find actions explicitly and effectively aimed at ensuring urban health as "a state of complete physical, mental and social well-being and not merely the absence of disease or infirmity" [131], at removing obstacles due to "race, religion, political belief, economic or social condition" [131], and at pursuing "peace" [131]. Rather, when not explicitly presented as a commodity, health is considered as a trigger of economic growth and prosperity: this happens in the first paragraph of Copenhagen's vision, in the only bolded paragraph of the executive summary of London's strategy, and in Berlin's "green growth" dream. Resorting to previous systemic thoughts offered in Cristiano and Gonella [38], the guiding goal of these systems seems still bound to profit for economic growth, while pursuing health and well-being may be considered as a side target that is functional to that-and its potential for success is perhaps far from being proven, thus laying the basis for further research. However, as per systems thinking teachings, a suitable definition of the systemic goal is the most powerful leverage point, and this is the second crucial step to stress; here, it would be about the restoration of the ideal goal of a city, i.e., the well-being of its inhabitants, not necessarily passing through the socially, environmentally, and often even economically problematic economic growth [132-134]. The importance of the environmental and the socioeconomic determinants of health (and health inequalities) is overall stressed in the selected case studies (analysis), yet systemically quite underexplored in the subsequent action proposals (synthesis). Such a mismatch may mark the road to look for a third crucial step, represented by a more effective leverage point, i.e., more courageously addressing the still recognised environmental and socioeconomic determinants of health at all levels, including the urban one. Parallel to this, a fourth crucial step can be identified both for growth-oriented and for health-oriented goals; as a matter of fact, a rare guiding question seems absent, i.e., "growth for whom?", "health and well-being for whom?", thus opening a further option for further research to be possibly developed, maybe keeping in mind that urban planning has been attributed "strong and precise responsibilities in the worsening of inequalities" in what Secchi [135] defines as "the city of the rich and the city of the poor".

\section{Conclusions}

A novel approach, rooted in systems thinking and in the energy systems diagramming, is first used to study and evaluate urban health proposals in Global Northern cities and metropolises. Currently in force plans, policies, and/or strategies specifically or marginally addressing urban health are selected from four cities in Europe: Copenhagen, London, Berlin, and Vienna. Building on previous diagrams for urban systems and on the analyses 
presented in these case studies, a new systems diagram is drawn to explore how such urban health proposals relate to health, as defined by the World Health Organisation. Specifically, the leverage potential for urban health is searched for in these proposals, also wondering whether any under- or overrated approach is present, and whether there is any action that is there neglected although promising in terms of leverage potential toward effectively achieving lasting urban health. Findings-targeted to both scholars, practitioners, and public officers in the areas of urban planning, urban governance, and public health - can be summarised as follows:

- A first-of-its-kind systems diagram is drawn, based on the energy systems language, presenting and highlighting some systemic connections between urban life and economy, socioeconomic determinants, and natural environment and green areas on the one side and urban health on the other.

- Crucial connections are represented among socioeconomic determinants and issues such as: waste and pollution, climate change, and urban warming (potentially yielding environmental justice issues); environment, green areas, and "green" infrastructures (potentially yielding issues related to the actual possibility to access and enjoy them across urban dweller categories with socioeconomic differences); unhealthy diet and habits (usually addressed downstream with awareness raising campaigns but still potentially fuelled upstream by socioeconomic determinants).

- Although with different levels of detail and concreteness, the four selected case studies tend to address (or wish someone addresses) some of the aforementioned issuessuch as waste and pollution, urban warming, green areas and infrastructures, and unhealthy diet and habits—-separately and downstream, i.e., mostly focusing on them as effects rather than tackling their causes, laying in the socioeconomic determinants, as also widely recognised in the introductions to the assessed policies.

- The selected urban health policy proposals seem to only partially relate to health, as defined by the World Health Organisation, thus encompassing the several features of health and well-being, and significantly addressing the socioeconomic obstacles to their achievement.

- From a systemic perspective, the actions proposed in the selected case studies do not seem to tackle urban health issues in their systemic leverage points, i.e., where action is expected to be more effective. In spite of systemically valid premises of all policies, the proposed efforts seem more focused on some effects rather than on common causes of health inequalities, generally recognised in socioeconomic determinants. Consulting, awareness-raising, and other forms of support to fight unhealthy diet and habits are common approaches throughout the selected case studies but seem to only act downstream, intervening upon the effects of recognised but under-addressed causes, i.e., socioeconomic determinants. Conversely, the most significant leverage points seem to lie in the systemic goal of cities-here still commonly and declaredly oriented to economic growth and prosperity and not to health and well-being as human rights or societal scopes, while still hardly addressing delicate yet crucial issues such as whose city, whose growth, and whose prosperity and thus whose health and whose well-being. Consequently, actions with high leverage potential can be found in addressing the socioeconomic determinants of health as structural socioeconomic inequalities inside urban life and economies, as well as in seriously urging environmental, climate change, and urban warming action also at a larger, global level. These are all intervention points where urban plans, policy proposals, and strategies are expected to start changing something if really aimed at achieving lasting urban health.

A novel approach studying urban health proposals has broadened the systemic knowledge of cities and public health and preliminarily identified crucial issues and leverage points. Building upon this and upon the ex post evaluation of four Global Northern strategies, further researches may more operationally accompany the development of urban 
planning and urban governance strategies, thus increasing the level of detail, differentiated by context, and also acting ex ante.

Author Contributions: Conceptualisation and design, S.C.; methodology, S.C.; systems diagram, S.C.; case study selection, S.Z.; writing-original draft preparation (introduction, abstract, and keywords), S.Z.; writing-original draft preparation (method and materials, results and discussion, and conclusion), S.C.; writing-review and editing, S.C. and S.Z.; supervision, S.C.; APC funding acquisition, S.C. All authors have read and agreed to the published version of the manuscript.

Funding: This research received no external funding.

Conflicts of Interest: The authors declare no conflict of interest.

\section{References}

1. Hensley, M.; Mateo-Babiano, D.; Minnery, J.; Pojani, D. How Diverging Interests in Public Health and Urban Planning Can Lead to Less Healthy Cities. J. Plan. Hist. 2020, 19, 71-89. [CrossRef]

2. Vojnovic, I.; Pearson, A.L.; Asiki, G.; DeVerteuil, G.; Allen, A. (Eds.) Handbook of Global Urban Health; Routledge: Abingdon, UK, 2019.

3. Brenner, N.; Marcuse, P.; Mayer, M. (Eds.) Cities for People, Not for Profit: Critical Urban Theory and the Right to the City; Routledge: Abingdon, UK, 2014.

4. Carmichael, L.; Townshend, T.G.; Fischer, T.B.; Lock, K.; Petrokofsky, C.; Sheppard, A.; Sweeting, D.; Ogilvie, F. Urban Planning as an Enabler of Urban Health: Challenges and Good Practice in England Following the 2012 Planning and Public Health Reforms. Land Use Policy 2019, 84, 154-162. [CrossRef]

5. The European Commission's Joint Research Centre. The Future of Cities: Opportunities, Challenges and the Way Forward; Publications office of the European Union: Luxembourg, 2019. [CrossRef]

6. World Bank. Urban Population (\% of Total Population) [Data file]. 2021. Available online: https://data.worldbank.org/indicator/ SP.URB.TOTL.IN.ZS (accessed on 8 October 2021).

7. United Nations, Department of Economic and Social Affairs, Population Division. World Urbanization Prospects: The 2018 Revision; United Nations Publications: New York, NY, USA, 2019.

8. United Nations. New Urban Agenda; United Nations Publications: New York, NY, USA, 2017.

9. United Nations. Transforming Our World: The 2030 Agenda for Sustainable Development; United Nations Publications: New York, NY, USA, 2015.

10. World Health Organization. Health as the Pulse of the New Urban Agenda; WHO Document Production Services: Geneve, Switzerland, 2016.

11. World Health Organization. Health Promotion Glossary; WHO Document Production Services: Geneve, Switzerland, 1998.

12. United Nations Children's Fund; WHO-World Health Organization. Declaration of Alma Ata; WHO Document Production Services: Geneve, Switzerland, 1978.

13. Nunes, B.P.; Thumé, E.; Tomasi, E.; Duro, S.M.S.; Facchini, L.A. Socioeconomic inequalities in the access to and quality of health care services. Rev. Saúde Pública 2014, 48, 968-976. [CrossRef] [PubMed]

14. Vlahov, D.; Boufford, J.I.; Pearson, C.E.; Norris, L. (Eds.) Urban Health: Global Perspective; Jossey-Bass: San Francisco, CA, USA 2010.

15. Stafford, M.; Marmot, M. Neighbourhood deprivation and health: Does it affect us all equally? Int. J. Epidemiol. 2003, 32, 357-366. [CrossRef] [PubMed]

16. UN-Habitat-United Nations Human Settlements Programme. World Cities Report 2020: The Value of Sustainable Urbanization; United Nations Publications: New York, NY, USA, 2020.

17. UN-Habitat-United Nations Human Settlements Programme; World Health Organization. Integrating Health in Urban and Territorial Planning: A Sourcebook; WHO Document Production Services: Geneve, Switzerland, 2020.

18. World Health Organization. Noncommunicable Diseases. 2021. Available online: https://www.who.int/news-room/fact-sheets/ detail/noncommunicable-diseases (accessed on 8 October 2021).

19. World Health Organization. Determinants of Health. 2017. Available online: https://www.who.int/news-room/q-a-detail/ determinants-of-health (accessed on 8 October 2021).

20. Seddon, N.; Chausson, A.; Berry, P.; Girardin, C.A.J.; Smith, A.; Turner, B. Understanding the value and limits of nature-based solutions to climate change and other global challenges. Philos. Trans. R. Soc. B 2020, 375, 20190120. [CrossRef]

21. Xie, L.; Bulkeley, H. Nature-based solutions for urban biodiversity governance. Environ. Sci. Policy 2020, 110, 77-87. [CrossRef]

22. MacKinnon, K.; van Ham, C.; Reilly, K.; Hopkins, J. Nature-Based Solutions and Protected Areas to Improve Urban Biodiversity and Health. In Biodiversity and Health in the Face of Climate Change; Marselle, M., Stadler, J., Korn, H., Irvine, K., Bonn, A., Eds.; Springer: Cham, Switzerland, 2019. [CrossRef]

23. European Commission. Communication from the Commission to the European Parliament, the European Council, the Council, the European Economic and Social Committee and the Committee of the Regions, The European Green Deal, COM (2019) 640 
final. 2019. Available online: https:/ / eur-lex.europa.eu/legal-content/EN/TXT/?uri=COM\%3A2019\%3A640\%3AFIN (accessed on 10 October 2021).

24. European Commission. Local Green Deals: A Blueprint for Action; Publications Office of the European Union: Luxembourg, 2021. [CrossRef]

25. Eckert, E.; Kovalevska, O. Sustainability in the European Union: Analyzing the discourse of the European Green Deal. J. Risk Financ. Manag. 2021, 14, 80. [CrossRef]

26. Abdullah, H. (Ed.) Towards a European Green Deal with Cities: The Urban Dimension of the EU's Sustainable Growth Strategy; Centre for International Affairs: Barcelona, Spain, 2021.

27. Krähmer, K. Are green cities sustainable? A degrowth critique of sustainable urban development in Copenhagen. Eur. Plan. Stud. 2021, 29, 1272-1289. [CrossRef]

28. Ståhl, T.; Wismar, M.; Ollila, E.; Lahtinen, E.; Leppo, K. Health in all Policies. Prospects and Potentials; Ministry of Social Affairs and Health: Helsinki, Finland, 2006.

29. Pinheiro, M.D.; Luís, N.C. COVID-19 could leverage a sustainable built environment. Sustainability 2020, 12, 5863. [CrossRef]

30. Vlahov, D.; Freudenberg, N.; Proietti, F.; Ompad, D.; Quinn, A.; Nandi, V.; Galea, S. Urban as a Determinant of Health. J. Urban Health Bull. N. Y. Acad. Med. 2007, 84, 16-26. [CrossRef]

31. Martínez, L.; Short, J.R. The Pandemic City: Urban issues in the time of COVID-19. Sustainability 2021, 13, 3295. [CrossRef]

32. Moreno, C. Droit de Cité: De la "Ville-Monde" à la Ville du Quart d'Heure; Les Éditions de l'Observatoire: Paris, France, 2020.

33. Moreno, C.; Allam, Z.; Chabaud, D.; Gall, C.; Pratlong, F. Introducing the "15-Minute City": Sustainability, Resilience and Place Identity in Future Post-Pandemic Cities. Smart Cities 2021, 4, 93-111. [CrossRef]

34. Pozoukidou, G.; Chatziyiannaki, Z. 15-Minute City: Decomposing the new urban planning eutopia. Sustainability 2021, 13, 928. [CrossRef]

35. C40 Cities. Mayors' Agenda for a Green and Just Recovery; C40 Cities: London, UK, 2020.

36. World Health Organization; UN-Habitat. Global Report on Urban Health; Equitable, Healthier Cities for Sustainable Development; WHO Document Production Services: Geneve, Switzerland, 2016.

37. Lovasi, G.S.; Roux, A.V.D.; Kolker, J. (Eds.) Urban Public Health: A Research Toolkit for Practice and Impact; Oxford University Press: Oxford, UK, 2020.

38. Cristiano, S.; Gonella, F. 'Kill Venice': A systems thinking conceptualisation of urban life, economy, and resilience in tourist cities. Humanit. Soc. Sci. Commun. 2020, 7, 143. [CrossRef]

39. Odum, H.T. Systems Ecology; An Introduction; Wiley: Hoboken, NJ, USA, 1983.

40. Sterman, J.D. Learning in and about complex systems. Syst. Dyn. Rev. 1994, 10, 291-330. [CrossRef]

41. von Bertalanffy, L. General System Theory: Foundations, Development, Applications; George Braziller: New York, NY, USA, 1968.

42. Forrester, J.W. Principles of Systems: Text and Workboo; Springer: Cham, Switzerland, 1973.

43. Ompad, D.C.; Tozan, Y. A Systems Science Approach to Urban Health. In Urban Health; Oxford University Press: New York, NY, USA, 2019; pp. 179-187.

44. Odum, H.T. Ecological and General Systems: An Introduction to Systems Ecology; University Press of Colorado: Niwot, CO, USA, 1994.

45. Odum, H.T. Environment, Power, and Society for the Twenty-First Century: The Hierarchy of Energy; Columbia University Press: New York, NY, USA, 2007.

46. Capra, F. Criteria of systems thinking. Futures 1985, 17, 475-478. [CrossRef]

47. Ballé, M. Managing with Systems Thinking: Making Dynamics Work for You in Business Decision Making; McGraw-Hill International: London, UK, 1994.

48. Haines, S. The Systems Thinking Approach to Strategic Planning and Management; CRC Press: Boca Raton, FL, USA, 2016.

49. Meadows, D.H. Thinking in Systems: A Primer; Chelsea Green Publishing: White River Junction, VT, USA, 2008.

50. Cristiano, S.; Gonella, F. To build or not to build? Megaprojects, resources, and environment: An emergy synthesis for a systemic evaluation of a major highway expansion. J. Clean. Prod. 2019, 223, 772-789. [CrossRef]

51. Luna-Reyes, L.F.; Andersen, D.L. Collecting and analyzing qualitative data for system dynamics: Methods and models. Syst. Dyn. Rev. J. Syst. Dyn. Soc. 2003, 19, 271-296. [CrossRef]

52. Bellinger, G. Translating Systems Thinking Diagrams to Stock \& Flow Diagrams. 2004. Available online: http://www.systemsthinking.org/stsf/stsf.htm (accessed on 27 July 2021).

53. Gonella, F.; Casazza, M.; Cristiano, S.; Romano, A. Addressing COVID-19 Communication and Management by a Systems Thinking approach. Front. Commun. 2020, 5, 63. [CrossRef]

54. Bossel, H. Systems and Models: Complexity, Dynamics, Evolution, Sustainability; Books on Demand: Norderstedt, Germany, 2007.

55. Meadows, D.H. Leverage Points: Places to Intervene in a System; The Sustainability Institute: Hartland, VT, USA, 1999.

56. Odum, H.T.; Peterson, L.L. Relationship of energy and complexity and planning. Archit. Des. 1972, 10, 624-629.

57. Mandelbaum, S.J. Thinking about cities as systems: Reflections on the history of an idea. J. Urban Hist. 1985, 11, 139-150. [CrossRef]

58. Sanders, T.I. Complex systems thinking and new urbanism. New Urban. Beyond Des. Cities Future 2008, 10, $275-279$.

59. Davidson, K.M.; Venning, J. Sustainability decision-making frameworks and the application of systems thinking: An urban context. Local Environ. 2011, 16, 213-228. [CrossRef]

60. Orr, D. Systems thinking and the future of cities. Solutions 2014, 5, 54-61. 
61. Bedinger, M.; Beevers, L.; Walker, G.H.; Visser-Quinn, A.; McClymont, K. Urban systems: Mapping interdependencies and outcomes to support systems thinking. Earth's Future 2020, 8, e2019EF001389. [CrossRef]

62. Scrieciu, S.Ş.; Zimmermann, N.; Chalabi, Z.; Davies, M. Linking complexity economics and systems thinking, with illustrative discussions of urban sustainability. Camb. J. Econ. 2021, 45, 695-722. [CrossRef]

63. Caputo, F.; Walletzky, L.; Štepánek, P. Towards a systems thinking based view for the governance of a smart city's ecosystem: A bridge to link Smart Technologies and Big Data. Kybernetes 2019, 48, 108-123. [CrossRef]

64. Amaba, B.A. Industrial and Business Systems for Smart Cities. In Proceedings of the 1st International Workshop on Emerging Multimedia Applications and Services for Smart Cities, Orlando, FL, USA, 7 November 2014; pp. 21-22. [CrossRef]

65. Saviano, M.; Caputo, F.; Formisano, V.; Walletzký, L. From Theory to Practice: Applying Systems Thinking to Smart Cities. In Proceedings of the 4th International Symposium Advances in Business Management. "Towards Systemic Approach", Vilnius, Lithuania, 24-26 August 2016; pp. 35-40.

66. Abbas, H.; Shaheen, S.; Elhoseny, M.; Singh, A.K.; Alkhambashi, M. Systems thinking for developing sustainable complex smart cities based on self-regulated agent systems and fog computing. Sustain. Comput. Inform. Syst. 2018, 19, 204-213. [CrossRef]

67. Singh, A.; Singla, A.R. Constructing definition of smart cities from systems thinking view. Kybernetes 2020, 50, 1919-1950. [CrossRef]

68. Xue, J.; Liu, G.; Casazza, M.; Ulgiati, S. Development of an urban FEW nexus online analyzer to support urban circular economy strategy planning. Energy 2018, 164, 475-495. [CrossRef]

69. Xue, J.; Cristiano, S.; Casazza, M.; Nawab, M.; Ghisellini, P.; Ulgiati, S. Development of an Urban Household Food-Energy-Water Policy Nexus Dynamic Simulator. J. Clean. Prod. 2021, 328, 129521. [CrossRef]

70. Pollock, K. Policy: Urban physics. Nature 2016, 531, S64-S66. [CrossRef]

71. Cristiano, S.; Zucaro, A.; Liu, G.; Ulgiati, S.; Gonella, F. On the systemic features of urban systems: A look at material flows and cultural dimensions to address post-growth resilience and sustainability. Front. Sustain. Cities 2020, 2, 12. [CrossRef]

72. Lammers, J.C.; Pandita, V. Applying systems thinking to public health leadership. J. Public Health Manag. Pract. 1997, 3, 39-49. [CrossRef] [PubMed]

73. McLeroy, K. Thinking of Systems. Am. J. Public Health 2006, 96, 402. [CrossRef]

74. Chughtai, S.; Blanchet, K. Systems thinking in public health: A bibliographic contribution to a meta-narrative review. Health Policy Plan. 2017, 32, 585-594. [CrossRef]

75. Peters, D.H. The application of systems thinking in health: Why use systems thinking? Health Res. Policy Syst. 2014, 12, 51. [CrossRef]

76. Adam, T. Advancing the application of systems thinking in health. Health Res. Policy Syst. 2014, 12, 50. [CrossRef]

77. Sarriot, E.G.; Kouletio, M.; Jahan, S.; Rasul, I.; Musha, A.K.M. Advancing the application of systems thinking in health: Sustainability evaluation as learning and sense-making in a complex urban health system in Northern Bangladesh. Health Res. Policy Syst. 2014, 12, 45. [CrossRef]

78. Rwashana, A.S.; Nakubulwa, S.; Nakakeeto-Kijjambu, M.; Adam, T. Advancing the application of systems thinking in health: Understanding the dynamics of neonatal mortality in Uganda. Health Res. Policy Syst. 2014, 12, 36. [CrossRef]

79. Agyepong, I.A.; Aryeetey, G.C.; Nonvignon, J.; Asenso-Boadi, F.; Dzikunu, H.; Antwi, E.; Ankrah, D.; Adjei-Acquah, C.; Esena, R.; Aikins, M.; et al. Advancing the application of systems thinking in health: Provider payment and service supply behaviour and incentives in the Ghana National Health Insurance Scheme-A systems approach. Health Res. Policy Syst. 2014, 12, 35. [CrossRef]

80. Varghese, J.; Kutty, V.R.; Paina, L.; Adam, T. Advancing the application of systems thinking in health: Understanding the growing complexity governing immunization services in Kerala, India. Health Res. Policy Syst. 2014, 12, 47. [CrossRef]

81. Proust, K.; Newell, B.; Brown, H.; Capon, A.; Browne, C.; Burton, A.; Dixon, J.; Mu, L.; Zarafu, M. Human health and climate change: Leverage points for adaptation in urban environments. Int. J. Environ. Res. Public Health 2012, 9, 2134-2158. [CrossRef] [PubMed]

82. Battle-Fisher, M. Application of Systems Thinking to Health Policy E Public Health Ethics: Public Health and Private Illness; Springer: Cham, Switzerland, 2014.

83. Bishai, D.; Paina, L.; Li, Q.; Peters, D.H.; Hyder, A.A. Advancing the application of systems thinking in health: Why cure crowds out prevention. Health Res. Policy Syst. 2014, 12, 28. [CrossRef]

84. Williams, J.C. A systems thinking approach to analysis of the Patient Protection and Affordable Care Act. J. Public Health Manag. Pract. 2015, 21, 6-11. [CrossRef]

85. Carey, G.; Malbon, E.; Carey, N.; Joyce, A.; Crammond, B.; Carey, A. Systems science and systems thinking for public health: A systematic review of the field. BMJ Open 2015, 5, e009002. [CrossRef] [PubMed]

86. Berry, H.L.; Waite, T.D.; Dear, K.B.; Capon, A.G.; Murray, V. The case for systems thinking about climate change and mental health. Nat. Clim. Chang. 2018, 8, 282-290. [CrossRef]

87. Knai, C.; Petticrew, M.; Mays, N.; Capewell, S.; Cassidy, R.; Cummins, S.; Eastmure, E.; Fafard, P.; Hawkins, B.; Jensen, J.D.; et al. Systems thinking as a framework for analyzing commercial determinants of health. Milbank Q. 2018, 96, 472-498. [CrossRef]

88. Clarke, B.; Swinburn, B.; Sacks, G. Understanding the LiveLighter®obesity prevention policy processes: An investigation using political science and systems thinking. Soc. Sci. Med. 2020, 246, 112757. [CrossRef]

89. Li, Y.; Urich, P.; Yin, C. Systems Approach for Climate Change Impacts on Urban Health: Conceptual Framework, Modelling and Practice. In Urban Health Risk and Resilience in Asian Cities; Springer: Singapore, 2020; pp. 3-31. 
90. Pongsiri, M.J.; Gatzweiler, F.W.; Bassi, A.M.; Haines, A.; Demassieux, F. The need for a systems approach to planetary health. Lancet Planet. Health 2017, 1, e257-e259. [CrossRef]

91. Hussain, S.; Javadi, D.; Andrey, J.; Ghaffar, A.; Labonté, R. Health intersectoralism in the Sustainable Development Goal era: From theory to practice. Glob. Health 2020, 16, 15. [CrossRef] [PubMed]

92. Haley, D.; Paucar-Caceres, A.; Schlindwein, S. A Critical Inquiry into the Value of Systems Thinking in the Time of COVID-19 Crisis. Systems 2021, 9, 13. [CrossRef]

93. Cristiano, S.; Ulgiati, S.; Gonella, F. Systemic sustainability and resilience assessment of health systems, addressing global societal priorities: Learnings from a top nonprofit hospital in a bioclimatic building in Africa. Renew. Sustain. Energy Rev. 2021, 141, 110765. [CrossRef]

94. Romano, A.; Casazza, M.; Gonella, F. Addressing Non-linear System Dynamics of Single-Strand RNA Virus-Host Interaction. Front. Microbiol. 2021, 11, 3400. [CrossRef]

95. Cazzagon, V.; Romano, A.; Gonella, F. Using stock-flow diagrams to visualize theranostic approaches to solid tumors in personalized nanomedicine. Front. Bioeng. Biotechnol. 2021, 9, 604. [CrossRef] [PubMed]

96. Tozan, Y.; Ompad, D.C. Complexity and dynamism from an urban health perspective: A rationale for a system dynamics approach. J. Urban Health 2015, 92, 490-501. [CrossRef]

97. Roux, A.V.D. Health in cities: Is a systems approach needed? Cad. Saude Publica 2015, 31, 9-13. [CrossRef]

98. Newell, B.; Siri, J. A role for low-order system dynamics models in urban health policy making. Environ. Int. 2016, 95, 93-97. [CrossRef] [PubMed]

99. Auchincloss, A.H.; Garcia, L.M.T. Brief introductory guide to agent-based modeling and an illustration from urban health research. Cad. Saude Publica 2015, 31, 65-78. [CrossRef]

100. Lawrence, R.; Capon, A.; Siri, J. Lessons from Hippocrates for contemporary urban health challenges. Cities Health 2017, 1, 72-82. [CrossRef]

101. Kim, D.H.; Chung, C.K.; Lee, J.; Kim, K.K.; JeKarl, J.; Yoo, S. A systems thinking approach to explore the structure of urban walking and health promotion in Seoul. Korean J. Health Educ. Promot. 2018, 35, 1-16. [CrossRef]

102. Tan, D.T.; Siri, J.G.; Gong, Y.; Ong, B.; Lim, S.C.; MacGillivray, B.H.; Marsden, T. Systems approaches for localising the SDGs: Co-production of place-based case studies. Glob. Health 2019, 15, 85. [CrossRef]

103. Siri, J.; Tan, D. A Systems Approach to Urban Health and Well-being Has Come of Age in the Asia-Pacific Region. In Urban Health and Wellbeing Programme; Springer: Singapore, 2020; pp. 7-14. [CrossRef]

104. Pineo, H.; Zimmermann, N.; Davies, M. Integrating health into the complex urban planning policy and decision-making context: A systems thinking analysis. Palgrave Commun. 2020, 6, 21. [CrossRef]

105. Rupprecht, C.D.; Vervoort, J.; Berthelsen, C.; Mangnus, A.; Osborne, N.; Thompson, K.; Urushima, A.; Kovskaya, M.; Speigelberg, M.; Cristiano, S.; et al. Multispecies sustainability. Glob. Sustain. 2020, 3, 1-12. [CrossRef]

106. de Oliveira Morais, L.M.; Kuhlberg, J.; Ballard, E.; Indvik, K.; Rocha, S.C.; Sales, D.M.; de Oliveira Cardoso, L.; Gouveia, N.; de Lima Friche, A.A.; Caiaffa, W.T. Promoting knowledge to policy translation for urban health using community-based system dynamics in Brazil. Health Res. Policy Syst. 2021, 19, 53. [CrossRef]

107. Browne, J.; Walker, T.; Brown, A.; Sherriff, S.; Christidis, R.; Egan, M.; Versace, V.; Allendera, S.; Backholer, K. Systems thinking for Aboriginal Health: Understanding the value and acceptability of group model building approaches. SSM-Popul. Health 2021, 15, 100874. [CrossRef] [PubMed]

108. Liu, J. Financing and Implementing Resilience with a Systems Approach in Beirut. In Urban Health and Wellbeing Programme; Springer: Singapore, 2020; pp. 49-56.

109. Liu, J.; Gatzweiler, F.W.; Kumar, M. An evolutionary complex systems perspective on urban health. Socio-Econ. Plan. Sci. 2021, 75, 100815. [CrossRef]

110. Pineo, H.; Audia, C.; Black, D.; French, M.; Gemmell, E.; Lovasi, G.S.; Milner, J.; Montes, F.; Niu, Y.; Pérez-Ferrer, C.; et al. Building a methodological foundation for impactful urban planetary health science. J. Urban Health 2021, 98, 442-452. [CrossRef]

111. National Academies of Sciences, Engineering, and Medicine; Health and Medicine Division; Board on Global Health; Forum on Public-Private Partnerships for Global Health and Safety. Health-Focused Public-Private Partnerships in the Urban Context, Proceedings of the Workshop, Washington, DC, USA, 13-14 June 2019; Moerder, C., Hamilton, L., Alper, J., Eds.; National Academies Press: Washington, DC, USA, 2020.

112. World Health Organization. Basic Documents, 49th ed.; WHO Document Production Services: Geneve, Switzerland, 2020.

113. Eurostat. Population on 1 January by Age Groups and Sex-Cities and Greater Cities (urb_cpop1). 2021. Available online: https:/ / ec.europa.eu/eurostat/web/cities/data/database (accessed on 20 October 2021).

114. Economist Intelligence Unit. The Global Liveability Index 2019. Available online: https://www.eiu.com/public/topical_report. aspx?campaignid=liveability2019 (accessed on 20 October 2021).

115. Greater London Authority. The London Health Inequalities Strategies; Greater London Authority: London, UK, 2018; ISBN 978-1-84781-703-7.

116. City of Copenhagen. Enjoy life, Copenhagen. City of Copenhagen Health Policy 2015-2025. 2015. Available online: www.kk.dk (accessed on 28 July 2021).

117. Berlin SDUDE-Senate Department for Urban Development and the Environment. Berlin Strategy. Urban Development Concept Berlin 2030; Berlin SDUDE-Senate Department for Urban Development and the Environment: Berlin, Germany, 2014. 
118. Vienna Municipal Administration. The Smart City Wien Framework Strategy 2019-2050. Available online: https:/ /smartcity. wien.gv.at/site/ (accessed on 10 October 2021).

119. Yilmaz, K. Comparison of Quantitative and Qualitative Research Traditions: Epistemological, theoretical, and methodological differences. Eur. J. Educ. 2013, 48, 311-325. [CrossRef]

120. Poulis, K.; Poulis, E.; Plakoyiannaki, E. The role of context in case study selection: An international business perspective. Int. Bus. Rev. 2013, 22, 304-314. [CrossRef]

121. Patton, M.Q. Qualitative Research E Evaluation Methods, 4th ed.; SAGE Publications: Thousand Oaks, CA, USA, 2014.

122. Dahlgren, G.; Whitehead, M. Policies and Strategies to Promote Social Equity in Health. Background Document to WHO-Strategy Paper for Europe; Institute for Futures Studies: Stockholm, Sweden, 1991.

123. Barton, H.; Grant, M. A health map for the local human habitat. J. R. Soc. Promot. Health 2006, 126, 252. [CrossRef] [PubMed]

124. Parrique, T.; Barth, J.; Briens, F.; Kerschner, C.; Kraus-Polk, A.; Kuokkanen, A.; Spangenberg, J.H. Decoupling debunked. Evidence and Arguments Against Green Growth as a Sole Strategy for Sustainability. A Study Edited by the European Environment Bureau EEB; European Environmental Bureau: Bruxelles, Belgium, 2019.

125. Farrimond, H.R. 'Being a smoker': Investigating Smoking Identities in Different Socio-Economic Groups in England; University of London: London, UK, 2007.

126. Wood, G. 1. Reformers, Employers, and the Dangers of Working-Class Smoking. In Clearing the Air; Cornell University Press: Ithaca, NY, USA, 2016; pp. 10-39.

127. Mohai, P.; Pellow, D.; Roberts, J.T. Environmental justice. Annu. Rev. Environ. Resour. 2009, 34, 405-430. [CrossRef]

128. Hanke, C.; Hüelsmann, M.; Fornahl, D. Socio-Economic Aspects of Electric Vehicles: A literature Review. In Evolutionary Paths towards the Mobility Patterns of the Future; Springer: Cham, Switzerland, 2014; pp. 13-36.

129. Srinivasan, R.; Moe, K. The Hierarchy of Energy in Architecture: Emergy Analysis; Routledge: Abingdon, UK, 2015.

130. United Nations. Universal declaration of human rights; UN General Assembly: New York, NY, USA, 1948.

131. World Health Organization, Regional Office for Europe. City Responses through COVID-19. 2020. Available online: https: //www.euro.who.int/en/health-topics/environment-and-health/urban-health/who-european-healthy-cities-network/thewho-european-healthy-cities-network-a-response-to-the-covid-19-pandemic-close-to-the-people/city-responses-throughcovid-19 (accessed on 20 July 2021).

132. Meadows, D.; Randers, J. The Limits to Growth: The 30-Year Update; Routledge: Abingdon, UK, 2012.

133. Hirsch, F. Social Limits to Growth; Harvard University Press: Cambridge, MA, USA, 2013.

134. Kallis, G. Social Limits of Growth. In Degrowth; Routledge: Abingdon, UK, 2014; pp. 165-168.

135. Secchi, B. La Città dei Ricchi e la Città dei Poveri; Gius. Laterza \& Figli Spa: Bari, Italy, 2013. 